\title{
Amos' Call for Social Justice in Amos 5:21-24: A Model for Prophets in The Apostolic Church LAWNA, Nigeria
}

\author{
GodWin Olutayo Akintola (University OF SoUth AFrica)
}

\begin{abstract}
The book of Amos, particularly his message on social justice, has been of great interest in scholarship in recent times. However, the extent to which social justice issues manifest in the text and how they relate to modern context have not been fully explored. Following a careful reflection on the call for social justice in Amos 5:21-24 and informed by a justice-denying Nigerian context, could the theme of social justice, as reflected in the preceding text, inspire the prophets of The Apostolic Church LAWNA to proclaim a liberating and empowering message to the powers that be (political establishment), in solidarity with the poor and marginalised people of Nigeria? This concern is the main thrust of this article. Over the years, not only has the book of Amos become an inspiration for contemporary struggles against social oppression and injustice, the life and ministry of the prophet himself has become a model for pastors/prophets and crusaders of justice and righteousness today. In view of the prevailing social injustice and oppression in the Nigerian society, can the present-day prophets of The Apostolic Church LAWNA Nigeria be called upon to be as fearless as the eighth-century BCE Israelite prophets were, in raising their voices both within and outside the faith community to demand for a right and just society?
\end{abstract}

KEYWORDS: Social justice, Amos, prophecy, righteousness, ethical religion, worship, Nigeria, The Apostolic Church, LAWNA, prophetic ministry, injustice

\section{A PREAMBLE}

Prof Adamo ${ }^{1}$, an erudite Old Testament scholar, also stands out as one of the voices and prolific writers in African Biblical Hermeneutics. His contributions

* Submitted: 28/04/2021; peer-reviewed: 10/07/2021; accepted: 05/08/2021. Godwin Olutayo Akintola, “Amos' call for Social Justice in Amos 5:21-24-A Model for Prophets in The Apostolic Church LAWNA, Nigeria" 34 no. 2 (2021): 404 - 427. DOI: https://doi.org/10.17159/2312-3621/2021/v34n2a6.

1 My first encounter with the honouree, Prof DT Adamo was in 2002 at the Delta State University (DELSU) during the National Association of Biblical Studies (NABIS) academic conference. At the time, Prof Adamo was the Head of Department, Religious studies, DELSU and the Local Organising Chairman of the conference. It was such a 
to biblical scholarship, and I dare say, African Biblical Hermeneutics cannot be over-emphasised. His endless passion for spotlighting Africa and Africans in the Christian Bible in his scholarship is remarkable. Adamo believes that the Christian Bible can equally benefit the African people if the African context is allowed to interact with the biblical text. For Adamo, the Bible has enjoyed the hegemony of American and Eurocentric interpretations for too long rendering the African context redundant. Adamo therefore holds that no sound hermeneutics can be of benefit to the contemporary reader if it is not well situated within the context of the reader. Thus, Adamo's works focus on the decolonisation (or rather the de-Eurocentrisation) of the contents and methods of biblical scholarship especially as they are theorised and practised on the African continent, among others. ${ }^{2}$ His foregrounding of the African context in his interaction with the biblical text makes the Christian Bible living and dynamic in its application.

The present essay therefore engages with the text of Amos 5:21-24 in the context of The Apostolic Church, LAWNA, Nigeria.

\section{B INTRODUCTION}

Prophet Amos has been regarded as the earliest of all the classical prophets. ${ }^{3} \mathrm{He}$ came from a small town called Tekoa, which was situated in the hill country, south of Jerusalem. ${ }^{4}$ He lived in the first half of the eighth century BCE during the reigns of Jeroboam II (793-753 BC) in Israel and Uzziah (791-740) in Judah

humbling experience for me to come face-to-face with an erudite scholar whose works have influenced biblical scholarship globally. I had the privilege of conversing with him on how to navigate the road to becoming an Old Testament scholar. His advice and words of encouragement ignited the fire for the pursuit of my Masters' degree in Old Testament at the University of Ibadan in 2006. The honouree is not just a word class biblical scholar, he is a father with a large heart whose joy and passion it is to inspire and encourage young and aspiring scholars. In September 2015, I was privileged again to reconnect with him at the OTSSA/SASNES conference, held at Kwalata Lodge, Pretoria. At the conference, Prof Adamo asked me if I had completed my PhD. I told him I was yet to enrol for it. Then, he introduced me to Prof Madipoane Masenya (Ngwan'a Mphahlele) and asked if she would be willing to supervise my PhD. She agreed and I completed my PhD under her supervision in October 2020.

2 Madiapone Masenya (Ngwan'a Mphahlele), "Professor David Tuesday Adamo's Biblical Scholarship on Women: Reflections from an Africa-South African Mosadi," OTE 33/2 (2020): 348-362, DOI: https://doi.org/10.17159/2312-3621/2020/v33n2a11.

3 Bruce V. Malchow, Social Justice in the Hebrew Bible (Collegeville: The Liturgical Press, 1996).

4 Johannes G. Strydom and Wilhelm J. Wessels, Prophetic Perspective on Power and Social Justice (Pretoria: Biblia Publishers, 2000), 169. 
(Amos 1:1). Though he was from the southern kingdom of Judah, he prophesied in the northern kingdom. ${ }^{5}$

That Amos was a great prophet who was concerned with social justice is evident in his work. Scholars such as Keller ${ }^{6}$ also submit that the dominant theme of the book of Amos is social justice. According to Doorly ${ }^{7}$ Amos spoke of only one $\sin$, that is, the selfish greed of the rich and powerful of Samaria who prevented the fair distribution of the earth's resources among all the people of Israel. Woodbridge and Semmelink ${ }^{8}$ also assert that no prophet had a stronger voice for justice than Amos. The foregoing therefore explains why Christians, over the years, have drawn on Amos in their call for justice. Although Amos prophesied at a time of relative peace and prosperity, it was also a time when the Israelites neglected Yahweh's laws.

Amos spoke so vehemently against the increased disparity between the very wealthy and the extremely poor. He delivered the message of God to Israel when the economy was buoyant, and the rich were trampling on the poor. Meanwhile, maltreating the poor, the strangers and the vulnerable in the land was a grievous offence before God (Deut. 15:7-9). Amos did not hesitate to cry out to every group that trampled on the poor of the land. He proclaimed God's judgment over the nations (Amos 3:10), while pointing out that any nation that failed to do what was right and harboured violence and robbery should inevitably expect the wrath of God.

Although most scholars have engaged the book of Amos and especially the theme of social justice based on different academic parameters, little has been done on the theme of social justice specifically in Amos 5:21-24, as it relates to the role of prophets or clergy in The Apostolic Church LAWNA Nigeria (TACLN). Given a careful reflection on the call for social justice in Amos 5:2124 and informed by a justice-denying Nigerian context, could the theme of social justice, as reflected in the preceding text, inspire the prophets of The Apostolic Church LAWNA to proclaim a liberating and empowering message to the powers that be (political establishment) and in solidarity with the poor and marginalised people of Nigeria?

5 Strydom and Wessels, Prophetic Perspective on Power and Social Justice, 2000.

6 Page H. Kelley, Amos: Prophet of Social Justice (Grand Rapids: Baker Book House, 1972), 6 .

7 William J. Doorly, Prophet of Justice: Understanding the Book of Amos (Mahwah: Paulist Press, 1989), 88.

8 Noel Woodbridge and Willem Semmelink, "The Prophetic Witness of Amos and Its Relevance for Today's Church in African Countries for Promoting Social Justice, Especially in Democratic South Africa," Conspectus: The Journal of the South Africa Theological Seminary 16/9: 79-100, https://www.sats.edu.za/userfiles/Noel\%20Woodbridge.pdf. 
The study identifies social justice issues in Amos through a careful exegetical analysis of the text and its context. The discussion is marked by a comparative element because it establishes similarities between the phenomenon of the prophetic ministry in the Old Testament - in this case, the prophetic ministry of Amos - and the prophetic ministry in The Apostolic Church LAWNA Nigeria. However, it will also employ the African Biblical Hermeneutics approach. According to Adamo, "African Biblical hermeneutics is rereading the scripture from a premeditatedly Afrocentric perspective." 9 Rereading the biblical text Afrocentrically would indicate that one (that is, the African reader/interpreter) has accepted his or her socio-historical situatedness. The approach allows one to take seriously the plight of the African people in all that they do, which includes their hermeneutical endeavours ${ }^{10}$ For the purpose of this research, the Nigerian context is the immediate context within the broader African context that is under investigation.

\section{AMOS'CALL FOR SOCIAL JUSTICE (AMOS 5:21-24)}

\section{$1 \quad$ Text and translation}

1a The Hebrew Text: BHS

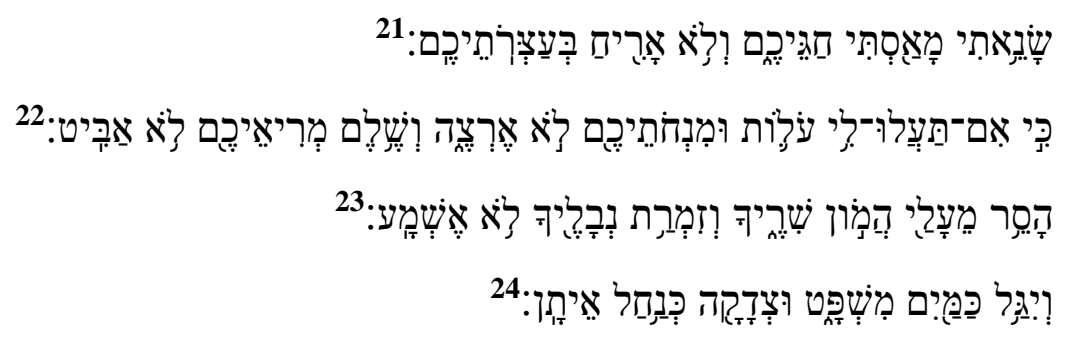

1b The English Translation

21 "I hate, I despise your feasts, and I take no delight in your solemn assemblies.

${ }^{22}$ Even though you offer me your burnt offerings and cereal offerings, I will not accept them, and the offerings of well-being of your fatted animals I will not look upon.

${ }^{23}$ Take away from me the noise of your songs; I will not listen to the melody of your harps.

9 David T. Adamo, "What Is African Biblical Hermeneutics?" Black Theology 13/1 (2015): 59-72; David T. Adamo, "The Task and Distinctiveness," OTE 28/1 (2015): 31-52.

10 Madipoane Masenya (Ngwan'a Mphahlele) and Hulisani Ramantswana, “Anything New under the Sun of African Biblical Hermeneutics in South African Old Testament Scholarship? Incarnation, Death and Resurrection of the Word in Africa," Verbum et Ecclesia 36/1 (2015): 1-12, https://dx.doi.org/10.4102/ve.v36i1.1353. 
${ }^{24}$ But let justice roll down like waters, and righteousness like an everflowing stream (NRSV). ${ }^{11}$

\section{$2 \quad$ Amos 5:21}

The verse starts with two very strong but forceful verbs juxtaposed asyndetically

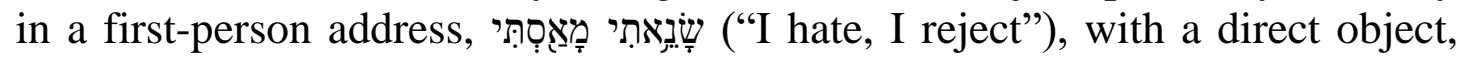

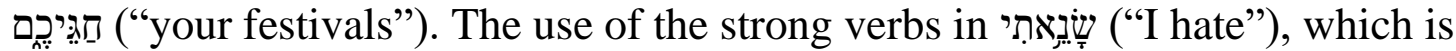

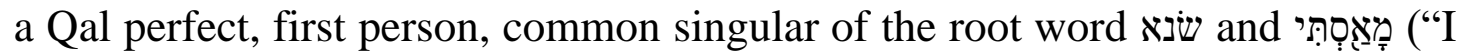
reject"), a Qal perfect, first person, common singular of the root word, מאס, מאס, indicates a shift into a "first-person speech." The first-person address form, opening this unit of verses 21-27, indicates that YHWH was the speaker in this passage, although the concluding speech formula in verse $27 \mathrm{~b}$ demonstrates that the prophet conveyed YHWH's speech. ${ }^{12}$ The direct object of YHWH's vexation and extreme rejection was the people's meaningless festivals- חַגירֶיסם (your festivals"). Paul ${ }^{13}$ notes that the substantive employed as the name for the three pilgrimage festivals (Exod 23:14-16; 34:22,

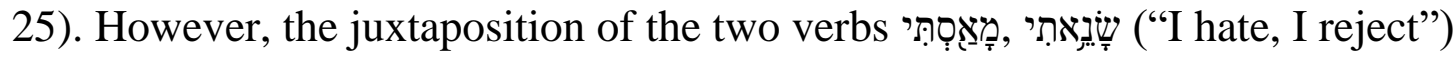
in the first part of the statement indicates how unambiguously YHWH detested and abhorred the basic elements of the Israelite cult. Garret ${ }^{14}$ also confirms that, "The anarthrous seconding of the first verb with another, near-synonymous verb eloquently expresses the disgust of someone who is weary of something tedious and irksome." Hence, YHWH's dissatisfaction and outright renunciation of northern Israel's feast days was expressed unequivocally in the first part of the text.

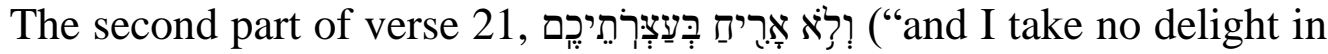
your solemn assemblies"), no doubt, again, indicates the intensity of YHWH's total disgust for the continuous religious errors of the people of Israel. It begins with a conjunctive waw plus a negative particle, וٕלֶא, the combination of which serves to "continue the train of thought begun by the preceding verbs that express negative emotions and serves to intensify the phrase that follows." 15 The word

${ }^{11}$ I have chosen the NRSV translation in the main text because it is closer to the Masoretic Text while, at the same time, its language is friendly to modern day Bible readers. The NRSV on the other hand, is wholistic and inclusive in terms of the gender aspect of translation while at the same staying true to the integrity of the Masoretic Text. In few cases however, allusions will be made to other translations where necessary for the sake of further exegetical clarity.

12 M.A. Sweeney, "Amos," in The Twelve Prophets, vol. 1: Hosea, Joel, Amos, Obadiah, Jonah (Berit Olam; Collegeville: Liturgical Press, 2000), 235-254.

${ }^{13}$ Shalom M. Paul, Amos (Hermeneia; Philadelphia: Fortress Press, 1991), 189.

${ }^{14}$ Duane A. Garrett, Amos: A Handbook on the Hebrew Text (Waco: Baylor University Press, 2008), 168.

15 Theresa V. Lafferty, "The Prophetic Critique of the Priority of the Cult: A Study of Amos 5:21-24 and Isaiah 1:10-17," (2012), 61 Unpublished PhD Thesis. The Catholic University of America, Washington, DC, USA. Online: 
ארָר is the Hiphil yiqtol, first person, common singular of the verb which means "to smell." 16 However, in this text, it is used in the negative to indicate YHWH's outright displeasure. Paul ${ }^{17}$ puts it more clearly thus:

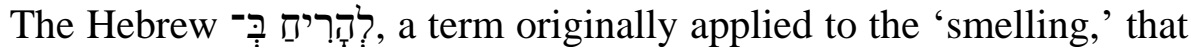
is, 'receiving favorably,' of sacrifice (for example, Gen 8:21; Exod 30:38; Lev 26:31; 1 Sam 26:19) here extended to apply to the disfavor

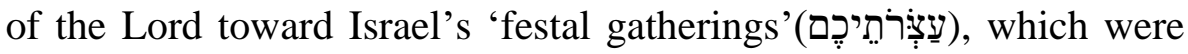
popular assemblies for the purpose of prayer and sacrifice during holidays or times of trouble; see Lev 23:36; Num 29:35; Deut 16:8; 2 Kgs 10:20; Isa 1:13; Joel 1:14; 2:15; Neh 8:18.

Therefore, Amos expressed YHWH's disapproval of Israel's solemn assemblies. The implication was that YHWH would not smell the soothing odour of the sacrifices that the people offered to Him in their solemn assemblies. The question that immediately comes to mind would be, why would YHWH refuse to savour the aroma of the very institution of worship which He Himself established; institutions which had technical significance within the cultic centre? However, from the text, it is obvious that YHWH does not refrain from quickly rejecting with utter hatred any religious institution or gathering that is not fulfilling its purpose. It appears that the people had become mechanical in their religious worship, that the soothing aroma of their sacrifices no longer smelled right before YHWH. What YHWH was more interested in, though, were their hearts, and not their baseless sacrifices. Thus, "the Lord affirms that because their hearts have turned from him and they use religion only as a mechanical means of pleasing (or appeasing) their God, he has no interest in the people's attachment to the cultic system that he himself instituted." ${ }^{18}$ Rather than producing a pleasant smell, Israel's worship produced a bad smell, which YHWH abhors. Arnold ${ }^{19}$ asserts that, "Israel's current worship, especially vis-àvis her cultic gatherings for sacrificial purposes, rather than creating a pleasing odour, left a malodorous stench. Hence, the offerings of the rich are unacceptable to Yahweh."

http://aladinrc.wrlc.org/bitstream/handle/1961/9205/Lafferty_cua_0043A_10087displ ay.pdf?sequence $=1$.

16 Garrett, Amos, 168.

17 Paul, Amos, 189.

18 Joseph Niehaus, "Amos," in The Minor Prophets: An Exegetical and Expository Commentary (Vol. 1: Hosea, Joel and Amos; Grand Rapids: Baker Book House, 1992), 315-494.

19 Mark D. Arnold, "The Ethics of Amos in Light of Its Ancient Near Eastern Context," MSU Graduate Theses (2012): 148, https://bearworks.missouristate.edu/theses/1. 


\section{$3 \quad$ Amos 5:22}

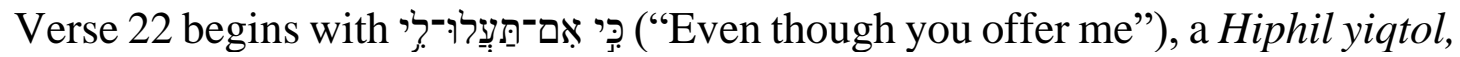

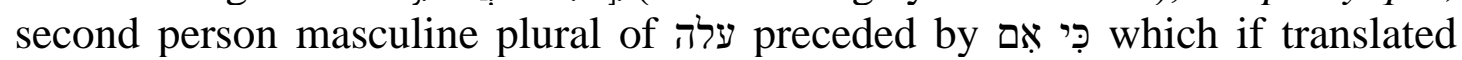
literally, would mean "for if." 20 There is much speculation among scholars as to how the interpretation of the introductory particles $\mathrm{R},{ }^{22}$ for instance, explains that some have understood "ִִ̣ "concussively," in which case, it would be interpreted ("even if"), while others prefer the "emphatic" interpretation ("surely if"). The third consideration ${ }^{23}$ is the conditional interpretation of כִּ "כִ which would be ("for if" or "even though"). The argument of the proponent of the concessional interpretation is that since the phrase כִּ comes after a negative (v. 21), it should carry a concessive function (as in Amos 3:7). However, there is no indication that, "the two words must be interpreted in such a fashion." ${ }^{24}$ For Carroll R, "whether "כִי "ִ is understood "concussively" (even if) or emphatically (surely if) the interruption by its length serves to underline the contrast between Israel's intent... and Yahweh's repulsion." The conditional interpretation of the particles would be preferred here, that is, "Even though you offer... I will not accept them." The preceding statement indicates that the action of the people did not align with YHWH's requirement, for their action does not justify their intention. Consequently, YHWH rejected their sacrifices and offerings completely because their actions were displeasing to Him. It must be noted that the aforementioned offerings were original aspects of Israel's Levitical heritage.

In verse 22, there is a repetition of the second person, plural pronominal suffix used to emphasise Yahweh's rejection of Israel's offerings - "even though you offer your grain offering, I (YHWH) reject them." 26 The deliberate use of you, your, and $I$ are quite instructive. With such grammatical devices, the text makes a clear distinction between the action of the audience (Israel) and the reaction of the speaker $(\mathrm{YHWH}) .{ }^{27}$ In other words, the action of the people in relation to their attitude towards sacrifice did not correspond with YHWH's

20 Garrett, Amos, 170.

21 John H. Hayes, Amos, His Time and His Preaching: The Eighth Century Prophet. (Nashville: Abingdon, 1988), 186; Paul, Amos, 190; Mark D. Carroll R., Contexts for Amos: Prophetic Poetics in Latin America Perspective (JSOT Sup 132; Sheffield: JSOT Press, 1992), 246; Richard J. Coggins, Joel and Amos: New Century Bible Commentary (Sheffield: Sheffield Academic Press, 2000), 131.

22 Carroll R., Contexts for Amos, 246.

23 Coggins, Joel and Amos, 131.

24 Paul, Amos, 190.

25 Carroll R., Contexts for Amos, 246.

26 Lafferty, "The Prophetic Critique," 61.

27 Lafferty, "The Prophetic Critique," 62. 
expectations. Hence, YHWH was indifferent to the cultic actions of the wealthy and powerful.

It is not unusual to associate such second person pronominal suffixes with cultic activities and festive celebrations in the biblical text. However, Amos' use of such grammatical devices indicates a disconnection between the people's celebration and Yahweh. The implication is that the people's celebrations did not have any positive effect on YHWH whenever Amos used the pronoun, "yours." 28

Klingbeil and Klingbeil ${ }^{29}$ describe the foregoing scenario as "a negative divine evaluation" of the people's cultic action since it was Israel that offered burnt offerings and meal offerings (and any other offering for that matter). YHWH's responsibility was to react at the end of the sacrifice with either a response of approval or a response of disapproval. In Amos 5:22, the prophet presented them with "a negative divine evaluation."

The first negative statement by YHWH is followed immediately by a second verb לא אַבָּיט ("I will not look upon”), which expressed YHWH's rejection of not only the burnt offering and the grain offering but also the peace offering or offering of well-being and fatted animals. Paul ${ }^{30}$ points out that the root (Hiphil) was never used in a cultic context except in the present text. For Wolf, ${ }^{31}$ the word customarily designates watching and paying attention to people (cf. Pss $13: 4$ [3]; 33:13; 80:15 [14]). Put more succinctly, the negative expression of the word renders the religious activities of the people unacceptable. Lafferty ${ }^{32}$ also writes that, "The use of the verb [as it occurs in the statement] recalls the phrase,

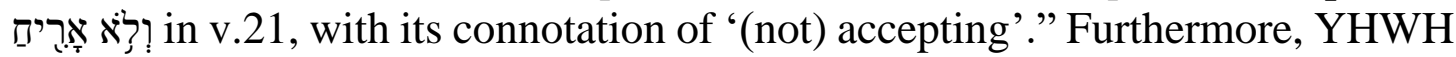
refused to subscribe to the people's sacrifices or look at them. Thus, the roots and רות in both cases fit the context in that they expand the idea of verse 21 to show that YHWH has now used his sense of sight to signify his refusal of the gifts of the people.

It is noteworthy that even though the offerings were an important aspect of Israel's Levitical heritage, they had lost their value before YHWH, as Israel had made them to become ends in themselves. The very core aspects of the lawlove for one's neighbour, caring for the poor and needy and caring for the widows and orphans - had been trampled underfoot. The people (wealthy elites and officials) thought that by their continued observances of religious rituals

28 Jorg Jeremias, The Book of Amos: A Commentary. Louisville: Westminster John Knox Press, 1998; Lafferty, "The Prophetic Critique," 61.

29 Gerald A. Klingbeil and Martin G. Klingbeil, "The Prophetic Voice of Amos as a Paradigm for Christians in the Public Square," Tyndale Bulletin 58/2 (2007): 161-182.

30 Paul, Amos, 190.

31 Hans W. Wolff, Amos and Joel (Philadelphia: Fortress Press, 1977), 263.

32 Lafferty, "The Prophetic Critique," 63. 
YHWH would be appeased and would consider them favourably. Notwithstanding,

The presence of the poor and oppressed, however, witnessed to their failure to please God. The neglected widow and their poor child in dirty rags were theological statement condemning the attitudes of the oppressors. Amos viewed the scriptures as objects of God's hatred because they furthered the spiritual ignorance of the people by giving them a false sense of security. ${ }^{33}$

\section{$4 \quad$ Amos 5:23}

Yahweh had not only rejected Israel's feast days and solemn assemblies (v.21), burnt offerings, grain offerings and meat offerings (v. 22), He also rejected their songs and the lyrics of their music. The first part of verse 23 reads:

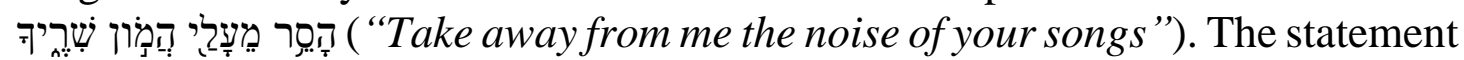
starts with דָָָסר primitive root word, סוּ, translated literally as "to turn off" or "take away." 34

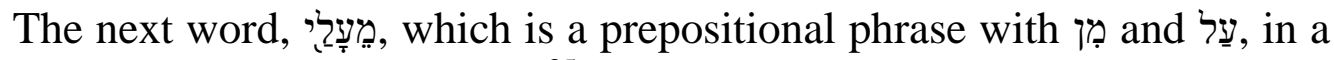
first person common singular suffix, ${ }^{35}$ could be translated "from upon me." The text reveals YHWH's continuous denunciation of, not only the people's cultic practice but also, their music and songs, which had become a heavy burden on him. Garrett ${ }^{36}$ argues that the proposition yives an impression that the people's music had become an unbearable burden in the ears of YHWH. Lafferty ${ }^{37}$ affirms

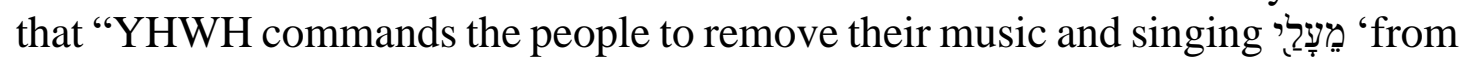
upon me,' thus suggesting that the weight of songs and music are heavy objects that are a burden to him."

It is troubling to note that YHWH regards the sound of their songs as "noisy" (דָהָמון), which according to Paul, ${ }^{38}$ is a word also used to describe the din of battle (see $1 \mathrm{Kgs} 20: 13$ ). It is used in the text as a singular masculine construct noun modifier to indicate a "noisy" sound. In its simple form, the meaning of the term הִּמֶון ranges from "murmur" to "tumult." Hence, Paul ${ }^{39}$ has suggested that the use of הָּמָון here most likely implies the sheer, ecstatic tumult of the singers

33 Niehaus, "Amos," 315-494.

34 James Strong, New Strong's Dictionary of Hebrew and Greek Words (Nashville:

Thomas Nelson, 1986), 98; Garrett, Amos, 171.

35 Garrett, Amos, 171.

36 Ibid.

37 Lafferty, "The Prophetic Critique," 64.

38 Paul, Amos, 263.

39 Ibid. 
at the harvest festivals. Whereas both Weiss ${ }^{40}$ and Lafferty ${ }^{41}$ suggest that, given its association with singing, the allusion to הָּמָ would be to the volume of the songs, whichever way it is viewed, it is obvious from the text that Israel's music or songs, regardless of how melodious and beautiful, was only "noise" in the ears of YHWH. The imperative particle הָסֵֵ ("take away"), which is a command, only serves to paint the outright rejection of Israel's singing, which was perceived as noise by YHWH.

A further corroboration of the divine disapproval of Israel's noisy songs

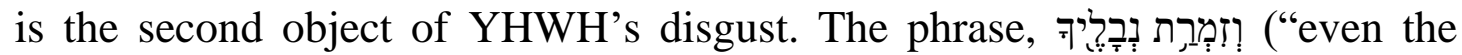
melody of your lyres"), which begins with the emphatic waw, suggests that YHWH would not listen to the people's songs or even to their music. The term

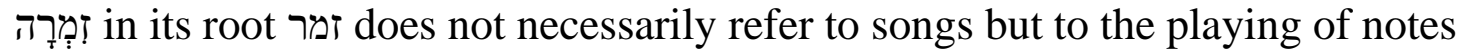
or as Paul ${ }^{42}$ has suggested, "it refers to music accompanied by an instrument." Hence, Weiss ${ }^{43}$ claims that the noun זִמְרָ connotes the music or melody that is played. Whereas the use of נָרָל here could be identified variously as a harp, lute, or lyre, Wolff" describes as "a stringed instrument, apparently with an angular yoke and a bulging resonance chamber." He notes that נֶָר is the oldest and most important stringed instrument in Israel and that it could have as many as ten strings. ${ }^{45}$ Even though music and the singing of psalms were essential aspects of Israel worship, in this instance, it became something that YHWH detested and would not listen to. Thus, "Music, which generally contains beautiful harmony and melodies with a soothing effect, is now experienced as burdensome by Yahweh." 46 YHWH had decided not to listen to the music of

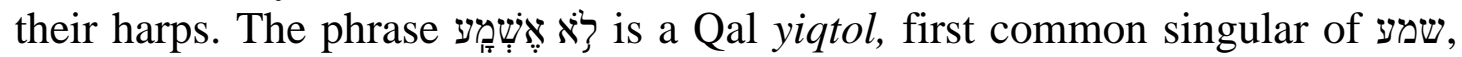
which is translated as "to hear." According to Garrett, ${ }^{47}$ the use of the first person yiqtol does not indicate a simple statement of the future, but rather, a forceful refusal to listen to such music. The implication of the preceding is that YHWH had made up his mind not to listen to such "annoying and soulless" music.

Interestingly but sadly, Amos expressed YHWH's total rejection and dissatisfaction of Israel's cultic activities through the use of anthropomorphic

40 Jacob Milgrom, Pomegranates and Golden Bells: Studies in Biblical, Jewish, and Near Eastern Ritual, Law, and Literature in Honor of Jacob Milgrom (Winona Lake: Eisenbrauns, 1995), 199-214.

41 Lafferty, "The Prophetic Critique," 64.

42 Paul, Amos, 192.

43 Weiss, "Concerning Amos' Repudiation of the Cult," 199-214.

44 Wolff, Joel and Amos, 264.

45 Ibid.

46 Kevin P. Wax, "The Intricate Relationship between Politics and Religion in the Hebrew Bible: The Prophet Amos as a Case Study," Unpublished PhD Thesis, Stellenbosch University, Stellenbosch, South Africa, 193file:///C:/Users/user/Downloads/wax_intricate_2013.pdf.

47 Garrett, Amos, 172. 
expressions to portray YHWH's total shutting off of his senses of smell, sight and hearing to Israel's sin. Paul ${ }^{48}$ asks the reader to "note that this total disavowal of the cult is expressed anthropomorphically by the Lord's shutting off, so to

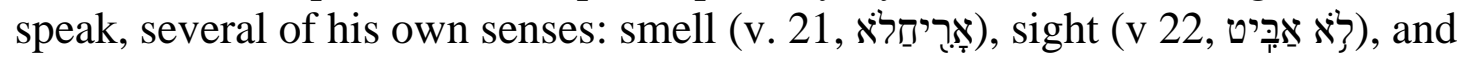

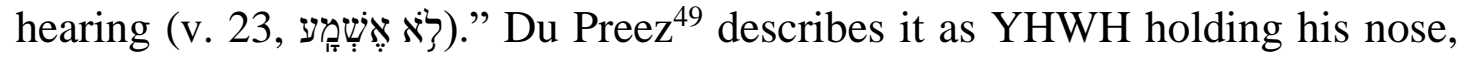
shutting his eyes and closing his ears to Israel's ceremonies, indicating YHWH's total disinterest and rejection of Israel's religious activities, which had only become a mere jamboree and distraction.

\section{$5 \quad$ Amos 5:24}

In Amos 5:24, Amos confronted his audience with the demand of YHWH for justice and righteousness in order to maintain order in society. ${ }^{50}$ Coggins refers to the demand as a positive requirement against which the condemnations in the previous verses are to be set. Further, גלי גלי ("but let...roll on") is from the root ("roll down, roll along"). ${ }^{51}$ Verse 24 begins with a Nifal imperfect ("let roll down"), preceded by an adversative waw ? ("but"), with a jussive force and it contrasts the soulless religiosity in verses $21-23$ with the desired ethical and moral action. ${ }^{52}$ In other words, the jussive form of the verb accentuates the contrast with the message of the three preceding verses (i.e. vv. 21-23). Indeed, the harsh tone of "I will not" that marks the preceding verse is replaced by a positive and encouraging tone of "let justice roll down..." seen as issuing a command for the people to take a specific action that would result in a positive outcome.

Various suggestions have been offered about the proper translation of נחל. Niehaus, ${ }^{54}$ for instance, has observed that the English word "stream," used for נחל in some translations, does not sufficiently capture the idea that "a wadi is a subterranean channel that transports torrents of water during the rainy season and dries to a trickle during the summer and is characteristic of the Middle East." 55 However, with the introduction of the adjective ("ever-flowing"), wadi

48 Paul, Amos, 192.

49 Jannie Du Preez, “'Let Justice Roll on Like...' Some Explanatory Notes on Amos 5:24," JTSA 109 (2001): 95-98.

50 John H. Hayes, Amos, His Time and His Preaching: The Eighth Century Prophet. (Nashville: Abingdon, 1988), 174.

51 Coggins, Joel and Amos, 132.

52 Garrett, Amos, 172; Mykola Leliovskyi, "Exegetical Study of Amos 5:18-27," (2015), https://www.academia.edu/14064690/Exegetical_Study_of_Amos_5_18-27.

53 Tochukwu Osuagwu, "An Ideological-critical Interpretation of Justice and Righteousness in Amos 5" (Unpublished MA Thesis, University of Pretoria, Pretoria, South Africa, 2016), 113, http://hdl.handle.net/2263/63000.

54 Niehaus, "Amos," 315-494.

55 See also Lafferty, "The Prophetic Critique," 69; Wax, "The Intricate Relationship between Politics and Religion," 194. 
assumes a fresh meaning. Wolff's ${ }^{56}$ rendering of the adjective איתן to mean "flowing voluminously" has become a widely accepted position. ${ }^{57}$ The implication of Wolff's translation is that even though a wadi is seasonal by nature איתן and has the tendency to dry up during the dry season, the use of the adjective ("ever-flowing") suggests that righteousness should be allowed to flow voluminously and unimpeded. For Hammershaimb, ${ }^{58}$ איתן could also be expressed as a "permanent" or "lasting" phenomenon. The implication of the preceding translation is that unlike the stream which only flows in the rainy season, the virtue of righteousness from the people should be allowed to flow continuously. Both translations of the איתל correspond with Amos' message in our text, which is, that justice and righteousness, like a wadi that never runs dry, should be allowed to flow abundantly and perpetually in order to sustain life in a society that was starved of the water of justice and righteousness. ${ }^{59}$

The value of the imagery of water employed by the prophet vividly portrays YHWH's expectation of justice and righteousness to flourish within the community of the covenant people. From the foregoing exegetical analysis of Amos 5:24, Amos' message is clear. Amos 5:24 is considered the pivot around which the whole book revolves. In the verse, the message of social justice, which is the central theme of the book, is succinctly presented in the command, "Let justice roll down like waters and righteousness like an ever-flowing stream." 60 Amos 5:24 is a call for a sound social order that will engender right humanhuman relationship and human-God relationship. This study agrees with Hyman's ${ }^{61}$ position that, "Amos 5:24 with its complex construction is a plea, an expressive exhortation to the people of Israel, in particular to the members of the upper class, to act justly and righteously instead of corruptly and immorally." Hyman $^{62}$ further argues that in the context of prophetic chastisement, Amos 5:24 is a call for social justice. Besides, 5:24 serves as a reminder to reject social injustice, which the prophet had consistently warned against in his oracles and embrace justice in order to avoid imminent doom.

\footnotetext{
56 Wolff, Joel and Amos, 264.

57 Coggins, Joel and Amos, 132; Wax, "The Intricate Relationship between Politics and Religion," 194.

58 Erling Hammershaimb, The Book of Amos: A Commentary (Oxford: Basil Blackwell, 1970), 90.

59 Coggins, Joel and Amos, 132.

60 Stephanus D. Snyman, “Amos, Prophet of God's Justice," in The Lion Has Roared. Theological Themes in the Prophetic Literature of the Old Testament (Eugene: Wipf \& Stock, 2012), 17-26; Michael U. Udoekpo, Rethinking the Prophetic Critique of Worship in Amos 5 for Contemporary Nigeria and the USA (Eugene: Pickwick, 2016), 17.

61 Hyman, "Amos 5:24," 4.

62 Ibid.
} 
Amos 5:24 also brings to light the reason YHWH was against the elaborate cultic activities in the previous verses (vv. 21-23). Having seen through the motives of his people, especially the upper class, YHWH proclaimed his utter rejection of their public display of worship and festive assemblies, not because those cultic activities were wrong in themselves, but because they were not founded on justice and righteousness. As a result, the people of Israel, and especially the upper class, failed to meet YHWH'S expectation of acting with

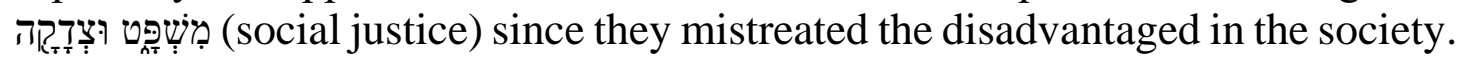
It is clear that Amos 5:24 did not deem the cultic worship in the previous verses unnecessary and undesirable. On the contrary, Amos maintained that, "the emphasis on ritual can be corrupting and inconsistent with the Lord's direction toward moral behavior." 63 In other words, bringing offerings to the Lord and singing ritual hymns are acceptable only when they accompany social actions that are consistent with the Lord's commandments on social justice and righteousness.

From the foregoing analysis, it is clear that Israel had disrupted the social order by abolishing justice and righteousness. The existence of class and hierarchy in the society was infringing on the very core of sound harmonious living and respect for the rights of others in the society. The cry of Amos to allow justice to roll down like waters and righteousness like an ever-flowing stream was not only a wakeup call but also a demand by YHWH for a state of sound social order.

At this point, I shall relate the theme of social justice in Amos to the present-day Nigerian context.

\section{AMOS 5:21-24 AND THE NIGERIAN CONTEXT}

If Prophet Amos were to live in Nigeria today, he would still have spoken the way he did to his audience, for the sins that Amos condemned in his day are very much alive in the contemporary Nigerian society. Folarin and Olanisebe ${ }^{64}$ agree that the situation of Israel at the time of Amos and the situation in the contemporary Nigerian society are similar. They argue that "oppression of the poor and the righteous, immorality, rejection of divine messages, pretentious religiosity, corruption in business, and idolatry, mark the two situations." 65 Similarly, Babalola ${ }^{66}$ highlights some of the indicators of social injustice in Nigeria, which include police brutality, genocide, use of child soldiers and child

63 Hyman, “Amos 5:24," 4

64 George O. Folarin and Samson O. Olanisebe, "Threat of Judgment in Amos and Its Lessons for Nigeria," European Scientific Journal 10/26 (2014): 246-261 (259).

65 Folarin and Olanisebe, "Threat of Judgment in Amos" 259.

66 James A.O. Babalola, "Social Injustice and Insecurity in Nigeria," Insight: Journal of Religious Studies 10/June/December (2014): 85-90. 
suicide bombers, poverty, discrimination, bullying, child labour, corruption, child prejudice, oppression, racism, cartelism and sexism.

Umeanolue $^{67}$ confirms that as in Amos' time, the situation in Nigeria is such that land, money and wealth rotate in the hands of the "high and the mighty" to the detriment of the poor. The implication is that the poor and the vulnerable survive only at the mercy of the few wealthy individuals. The population of Nigeria, according to the recent census, is above 200 million, but only about 10 percent controls the entire wealth of the country, ${ }^{68}$ leaving the vast majority of the populace in abject poverty. Umeanolue, ${ }^{69}$ in comparing the social injustice in Amos' time to that of the contemporary Nigerian society, identifies the various dimensions of social injustice in Nigeria as socio-economic injustice, sociopolitical injustice, socio-religious injustice and socio-judicial injustice.

In relating the text of Amos 5:21-24 to the Nigerian context, therefore, one basic correlation between the two contexts is that "both the audience of Amos and the contemporary Nigerian society are religious to a fault, but their religion is not positively reflected on their moral." 70 Nigerians are so religious that they would hardly take any major step in life without consulting the Supreme Being. Like the audience of Amos' time, the overwhelming enthusiasm of many worshippers at the centres of worship in Nigeria is quite remarkable. Unfortunately, though religion is flourishing in Nigeria, social injustice, corruption and poverty are on the increase. One would not have expected that a nation as zealously religious as Nigeria, would be classified among the three most corrupt nations in the world.

Like Amos' addressees who were condemned for their religious patronage of the cult and their flamboyant lifestyle at the cultic centre which was devoid of morality, most religious ${ }^{71}$ centres in Nigeria are also heavily patronised by worshippers who use religion as a mask to perpetuate their evil. The religious hypocrisy that Amos condemned in northern Israel is similar to that of the Nigerian context. Most of the vices and unethical behaviours in society are carried out by the same people who patronise the worship centres. Religion is expected to turn a society around positively and help improve a person's behaviour and lifestyle. ${ }^{72}$ However, in Nigeria, religion has produced the opposite. Rather than produce the fruit of righteousness, what is evident is the

67 Ikenna L. Umeanolue, "Critique against Social Injustice in the Book of Amos: Its Relevance to Development in Nigeria," UJAH 19/2 (2018): 182-198.

68 Umeanolue, "Critique against Social Injustice in the Book of Amos," 187.

69 Ibid., 187.

70 Folarin and Olanisebe, "Threat of Judgment in Amos," 259.

71 Three religions are recognised officially in Nigeria namely Christianity, Islam and African Traditional Religion. The emphasis here is on Christianity.

72 James O. Adeyanju, and Emmanuel O. Babalola, "The Gospel and the Impact of Poverty on the Practice of Ideal Christianity in Nigeria," IJRHSS 4/2 (2017): 22-30. 
fruit of "inequality, injustice and atrocities that one rarely encounters in the godless Scandinavian societies." 73 Indeed the religious corruption in Nigeria is at an alarming stage.

Amidst the social injustice and moral decadence of Amos' time, Amos identified a conspicuously religious people who were zealous in the worship of YHWH and actively involved at the various worship centres in Bethel, Gilgal and Beersheba (Amos 5:1-17, 5c, 27), but who, ironically indulged in the unethical behaviours proscribed by the law. Amos ministered to a people who were religiously zealous but ethically and morally deficient. The people were enthusiastic to appear always before YHWH but never sought the welfare and liberation of their fellow human beings. For this error, Amos unequivocally announced YHWH'S rejection and abhorrence of hypocrisy of their religious feasts and solemn assemblies (Amos 5:21).

The Nigerian situation is not different. It is common to see multitudes patronise worship centres. Presently, churches continue to spring up in the cities and even in the villages. A recent survey shows that there are about 1078 churches in Abuja, the national capital. ${ }^{74}$ Nigeria ranks among the nations with the highest number of churches in the world. ${ }^{75} \mathrm{~A}$ good example of the proliferation of churches is found on the Lagos-Ibadan expressway in the southwest of the country, which is gradually becoming the headquarters of many churches.

Some of the world's largest single church auditoriums are found also in Nigeria. Recently, a church in Abuja, Dunamis Christian Centre, built a 100 000seater auditorium, becoming the second 100 000-seater auditorium after that of The Apostolic Church in Lagos. There are also churches with large tents seating about 1.5 million people and others between 700000 and 1000000 people such as the Redeemed Christian Church of God and the Mountain of Fire and Miracle Ministries, respectively. Worshippers visit these worship centres in their hundreds of thousands for vigils, crusades, breakthrough services and conventions. What therefore is worrisome is that many of those in attendance are top government officials, political leaders, and people in privileged positions who are behind the oppression and injustice in the society. Most of these people go to church with the aim of getting God's blessing but religion is seen only as a tool for carrying out their selfish interests.

The question that most critical observers ask therefore is, with the proliferation of churches in Nigeria and with the high level of religious activities that take place in each of these centres, why is the country still in a deplorable

73 Adeyanju and Babalola, "The Gospel and the Impact of Poverty," 22-30.

74 Chris A. Otuibo, Amos: A Challenge to Nigerian Church and Society (Ibadan: St. Paul's Society, 2006), 67.

75 Adeyanju and Babalola, "The Gospel and the Impact of Poverty," 22-30. 
state? Why is there an increase in corruption, social injustice, kidnapping, oppression, police brutality, banditry and violence?

Amos' positive call for justice and righteousness becomes a relevant charge in addressing the sin of social injustice in Nigeria. The call for justice and righteousness is clearly understood as a call for social justice. It must be established that human beings have a role to play in the restoration of justice and righteousness in the society. In other words, restoring justice and righteousness should not only be seen as a divine initiative, rather, it is an action involving human beings. The understanding is that for any vertical relationship (human-God) to be intact, the horizontal relationship (human-human) must not suffer any strain. Consequently, the perpetuators of social injustice in Nigeria, like the audience of the northern Israel prophet, are called upon "to partner with [God] in establishing social justice, which involves actions done on behalf of the disadvantaged." 76

Authentic worship therefore must be matched with acts of kindness, justice and righteousness. These virtues, as demanded by Amos, must be allowed to flow voluminously and perpetually, like a stream, to marketplaces and the margins of the society. Udoekpo ${ }^{77}$ helps to put this section in perspective. He observes that, "In Nigeria, where religion has been repeatedly used as an instrument of oppression and characterised by religious violence, division, and acts of injustice rather than redemption, unity, and salvation, citizens should turn to the prophecy of Amos."

Thus, the call for the role of prophetic ministry in The Apostolic Church LAWNA, Nigeria should be extended to promote social justice in Nigeria as a whole.

\section{E AMOS' CALL FOR SOCIAL JUSTICE (AMOS 5:21-24)—A MODEL FOR PROPHETS IN TAC LAWNA}

As mentioned in the objective of this article, the major thrust of the article is to engage the prophetic ministry of Amos to challenge prophets of TAC LAWNA as the mouthpiece of God to confront the social injustices that are prevalent in the Nigerian society today.

\footnotetext{
76 Patrick K. Amissah, "Justice and Righteousness in the Prophecy of Amos and Their Relevance to Issues of Contemporary Social Justice in the Church in Ghana," 155, Unpublished $\mathrm{PhD}$ Thesis, King's College, London, https://kclpure.kcl.ac.uk/portal/files/51215526/2016_Amissah_Patrick_Kofi_0848210 ethesis.pdf. 77 Udoekpo, Rethinking the Prophetic Critique of Worship in Amos 5, 112.
} 
Over the years, not only has the book of Amos become an inspiration for contemporary struggles against social oppression and injustice, the life and ministry of the prophet himself has become a model for pastors/prophets and crusaders of justice and righteousness today. In view of the prevailing social injustice and oppression in Nigeria, the present-day prophets are called upon to be as fearless and audacious as the eighth-century BCE Israelite prophets in raising their voices both within and outside the faith community to demand for a right and just society.

Notably, the situation in Nigeria today can be likened to that of northern Israel during the time of Amos, in terms of the alarming levels of social injustice. The exploitation and oppression of the poor masses by the upper class of the society is unjustifiable, while the widening gap between the rich and the poor seems to be unbridgeable. Poverty and corruption at various levels of societal life are also on the increase.

The message of Amos therefore becomes relevant in efforts to conscientise the people of Nigeria to make the country a better place where people can live together in peace and harmony. In view of the prevailing social injustices and other social vices which are fast eroding the moral values in the Nigerian society, it is important to engage all available resources and machinery to address and reverse the current situation and maintain order. Consequently, the church, which is regarded as the light and beacon of hope of the society, needs to lend her prophetic voice to challenge the ruling elites by demanding for social justice in the land. As the salt and light of the earth, the church is summoned to influence the course of events in the world in order to create a just society where social justice and peace reign. ${ }^{78}$

The question therefore is can we find prophets today who will challenge the prevailing social and economic injustice in the Nigerian society? The present article calls on the prophets of The Apostolic Church in Nigeria to deploy their prophetic ministry to speak out in God's name against the social evils of the day. There is a need for prophetic voices that will not only promote social justice in Nigeria but also speak out on behalf of the victims of injustice.

Similarly, Pillay ${ }^{79}$ has called on the church in Africa not to limit herself within her four walls but to go public with her message of social transformation and change. The church therefore has a prophetic role to play in salvaging the nation from her abysmal fall. As the conscience of the nation, she is saddled with

78 Richard Adekoya, "The Church as a Stakeholder in the Socio-political Development of Society: The Example of Nigeria," Journal of the European Pentecostal Theological Association 38/1, DOI: 10.1080/18124461.2018.1434729.

79 Jerry Pillay, "The Church as a Transformation and Change Agent," HTS Teologiese Studies/Theological Studies 73/3 (2017), DOI: https://dx.doi.org/10.4102/hts.v73i3.4352. 
the responsibility of ensuring and fostering social justice through her God-given message of justice and righteousness. The church is to be at the forefront of denouncing any policy and programme that seeks to tamper with ethical values and cause economic devastation in the society. On the other hand, she is to support "the state where it implements policies and programmes which are in agreement with the deepest values of truth, justice, peace and human dignity." 80 Although the church should not have any active role in partisan politics, as Meyer ${ }^{81}$ has rightly argued, she can infiltrate politics with the love, principles, spirit and power of Christ. Thus:

[the church] does not take sides [in politics], except for the poor, oppressed and suffering; it takes sides in the sense of championing the poor regarding the gospel's demands of change in structures towards justice, equality, peace, compassion, reconciliation, and restitution.

It is important to remark that though the church in Nigeria has not been completely silent on issues of social justice, her voice also has not been loud enough.

Given the abovementioned prophetic role of the Church in stemming the tide of social injustice in Nigeria, the present work focuses specifically on The Apostolic Church, LAWNA Nigeria, and in particular, calls on the prophets of this denomination to use their prophetic ministry to demand for social justice in Nigeria. The reason for the choice of the context by the researcher is twofold. Firstly, the researcher is not only a member of the TAC, he is also an ordained pastor and one who has been troubled by the inaudible character of the church's prophetic voice on national issues that relate to social justice. Secondly, The Apostolic Church Nigeria is a leading Pentecostal church in the nation, with branches in almost all the cities and villages of Nigeria. TAC is arguably one of the largest denominations in the country. It has the world's largest church temple in Lagos which is the headquarters of The Apostolic Church Nigeria with a sitting capacity of 100000 worshippers at a time. ${ }^{82}$ Given her size and presence, the church should be able to influence the country positively through her prophetic ministry; but that has not been the case.

Prophets in TAC LAWNA are ordained ministers of God who are called and set apart with identifiable gifts of prophecy to declare the mind and will of

80 C.F.B. Naude, "A Vision for the Future," Christianity and Democracy in South Africa: Christian Responsibility for Political Reflection and Service. (Potchefstroom: The Institute for Reformational Studies, 1996), 255.

81 R. Meyer, "The Involvement of the Church in the Blueprints of Society," The Dutch Reformed Church in Africa, Supplement to the Ligstraal (October 1991): 10-18.

82 Sam Eyoboka and Olayinka Latona, "World's Largest Church Inaugurated in Lagos." Vanguard $12 \quad$ December 2011, http://www.vanguardngr.com/2011/12/world\%E2\%80\%99s-largestchurchinaugurated-in-lagos/. 
God to the people. Hence, prophets are regarded as the mouthpiece of God in the church and society. Through their prophecies, they guide, instruct, and direct the leadership of the church in making any administrative decision. The prophets also are charged with the role of calling people to a right walk with God. The question to ask is: To what extent have the prophets of The Apostolic Church LAWNA stood as agents of social change within the Nigerian society?

The Old Testament prophets, especially the eighth century prophets, did not confine their prophetic ministry to the cultic centres, but exercised their prophetic calling to address national issues with a view to producing social change (emancipation). The question therefore is where are the Amoses of our time who will roar in God's name against the prevalent social injustices in the Nigerian society? It is not enough for prophets of The Apostolic Church LAWNA to use their prophetic searchlight within the church; they are to stand also as the spiritual and moral conscience of the nation.

It must however be noted that over the years, that The Apostolic Church, LAWNA in Nigeria has tried, through Bible studies, sermons and daily ministrations, to utter her prophetic voice against the oppression of the poor, marginalisation of the masses and the monster called corruption which has plagued the Nigerian society. Her prophets have not been completely passive in raising their prophetic voices in solidarity with the poor, the needy and the hungry and the oppressed in Nigeria. According to Oyejimi, ${ }^{83}$ TAC prophets have not only engaged their prophetic ministry to condemn corruption and evil practices among members of the church, but on several occasions have condemned corruption, oppressive policies and practices in Nigeria. Like Prophet Amos, TAC prophets have challenged and condemned political, economic, social, religious and moral ills in Nigeria.

It is however the observation of the researcher that, though on few occasions, prophets of TAC LAWNA do speak against issues of social justice, corruption, poverty, inequality in Nigeria, such messages have only been heard by the body of believers within the four walls of the church. The people of influence outside the church who should also hear such a message have not been reached sufficiently. The prophets' voice has not been loud and consistent enough in a nation that is engrossed in the sin of social injustice. Indeed, Carter ${ }^{84}$ contends that if the contemporary church would adopt the tradition of the Old Testament prophets in persuading the government to do the right things,

83 Joseph A. Oyejimi, Prophetical Ministry in the Church (Ilesa: Living Truth Publisher, 2017), 105.

${ }^{84}$ Stephen S. Carter, God's Name in Vain: The Wrongs and Rights of Religion in Politics (New York: Basic Books, 2000), 13. See also Abraham Mbachirin, "The Will to Arise: Theological and Political Themes in African Christianity and the Renewal of Faith and Identity," Journal of Church and State 49/3 (2007): 566567, https://doi.org/10.1093/jcs/49.3.566. 
upholding justice and righteousness, then, she needs to raise her prophetic voice louder to give direction and to challenge the wrongdoings of the leaders. In view of the prevailing social injustice and corruption in the society, the prophetic ministry of the church should not remain silent since the church is called to be a public witness through its prophetic role.

It is important, therefore, to engage the prophetic ministry of Amos to challenge prophets of TAC LAWNA to take their message of social justice to the powerful in the society, become a voice to the voiceless, convey the will of God and unsettle the rich and the perpetrators of social injustice by insisting that society upholds social justice. As the mouthpiece of God, the prophets of TAC LAWNA should revisit their theology of sharing an 'inward-looking' message that seeks to focus only on the body of believers and consider an 'outwardlooking' message which seeks to influence the public audience.

\section{F CONCLUSION}

From the discussion above, the situation in Nigeria today is comparable to that of Amos' time. Today, Nigeria is saddled with many socio-economic, moral, political and religious problems. Social injustice pervades the land and leadership crisis is a reality in the country where a wide gap exists between the rich and the poor. Corruption at the highest level continues to characterise national development. Amos witnessed and challenged similar situations in the eighth century BCE Israel.

The message of Amos therefore becomes relevant in efforts to make Nigeria a better place where people can live together in peace and harmony. It challenges religious leaders in the society to act as the torchbearers of the moral and spiritual life of the nation. Priests, pastors and imams, like prophet Amos, should be uncompromising in denouncing the evil perpetrated by many of the so-called men of God and political leaders in the society.

Through the clergy, the church needs to amplify her voice against any act of injustice and corruption within her space. Prophets of TAC LAWNA, as the mouthpiece of God and promoters of morality, have the capacity to influence political leaders to uphold social justice. Like Amos, they should use their prophetic ministry to challenge members of the church to lead an exemplary life by shunning acts of exploitation and the oppression of the poor, widows and orphans in the church and in the society. The prophets of TAC LAWNA should use their prophetic ministry to equip and direct the members of the church and to stir the church on issues that pertain to social justice.

Moreover, the prophets should be bold enough to take their message to the corridors of power to challenge the corrupt judicial system where corrupt judges misuse their powers to pervert the course of justice through their unfair 
treatment of the innocent. It is time to hear the prophetic voice of TAC LAWNA as the voice of the voiceless and the moral conscience of the nation.

Let me at this point celebrate, again, the honouree, Prof Adamo, an icon in biblical scholarship who has been at the forefront of African Biblical Studies and who demonstrates that by engaging in sound African biblical hermeneutics interpreters also can bring about transformation in Africa. It is based on the preceding persuasion and methodological tool that this work has emerged. I am indebtedly grateful for the privilege to drink from the well of his scholastic experience, which has positively influenced my worldview and scholarship.

\section{G BIBLIOGRAPHY}

Adamo, David T. "What Is African Biblical Hermeneutics?" Black Theology 13/1 (2015): 59-72. DOI: 10.1179/1476994815Z.00000000047. ."The Task and Distinctiveness." Old Testament Essays 28/1 (2015): 31-52.

Adekoya, Richard. "The Church as a Stakeholder in the Socio-political Development of Society: The Example of Nigeria." Journal of the European Pentecostal Theological Association 38/1 (2018): 50-63. DOI: 10.1080/18124461.2018.1434729.

Adeyanju, James, O. Babalola and O. Emmanuel. "The Gospel and the Impact of Poverty on the Practice of Ideal Christianity in Nigeria." International Journal of Research in Humanities and Social Studies 4/2 (2017): 22-30.

Amissah, Patrick K. "Justice and Righteousness in the Prophecy of Amos and Their Relevance to Issues of Contemporary Social Justice in the Church in Ghana." Unpublished PhD Thesis. King's College, London. Cited 10 January 2021. Online:

https://kclpure.kcl.ac.uk/portal/files/51215526/2016_Amissah_Patrick_Kofi_0 848210_ethesis.pdf.

Arnold, Mark D. "The Ethics of Amos in Light of Its Ancient Near Eastern Context." MSU Graduate Theses (2012): 148. Cited 15 January 2021. Online: https://bearworks.missouristate.edu/theses/1.

Babalola, James A.O. "Social Injustice and Insecurity in Nigeria." Insight: Journal of Religious Studies 10 (June/December 2014): 85-90.

Carroll R., Mark D. Contexts for Amos: Prophetic Poetics in Latin America Perspective. Journal for the Study of the Old Testament Supplement Series 132. Sheffield: JSOT Press, 1992.

Carter, Stephen S. God's Name in Vain: The Wrongs and Rights of Religion in Politics. New York: Basic Books, 2000.

Coggins, Richard J. Joel and Amos: New Century Bible Commentary. Sheffield: Sheffield Academic Press, 2000.

Doorly, William J. Prophet of Justice: Understanding the Book of Amos. Mahwah: Paulist Press, 1989.

Du Preez, Jannie. “'Let Justice Roll on Like...' Some Explanatory Notes on Amos 5:24." Journal of Theology for Southern Africa 109 (2001): 95-98.

Eyoboka, Sam. Latona, Olayinka. "World's Largest Church Inaugurated in Lagos." Vanguard 12 December 2011. Cited 13 December 2020. Online: 
http://www.vanguardngr.com/2011/12/world\%E2\%80\%99s-largestchurchinaugurated-in-lagos/.

Folarin, George O. and Samson O. Olanisebe. "Threat of Judgment in Amos and Its Lessons for Nigeria.” European Scientific Journal 10/26 (2014): 246-261.

Garrett, Duane A. Amos: A Handbook on the Hebrew Text. Waco: Baylor University Press, 2008.

Hammershaimb, Erling. The Book of Amos: A Commentary. Oxford: Basil Blackwell, 1970.

Hayes, John H. Amos, His Time and His Preaching: The Eighth Century Prophet. Nashville: Abingdon, 1988.

Jeremias, Jorg. Der Prophet Amos. Das Alte Testament Deutsch 24, 2. Göttingen: Vandenhoeck \& Ruprecht, 1995.

Jeremias, Jorg. The Book of Amos: A Commentary. Louisville: Westminster John Knox Press, 1998.

Kelley, Page H. Amos: Prophet of Social Justice. Grand Rapids: Baker Book House, 1972.

Klingbeil, Gerald A. and Martin G. Klingbeil. "The Prophetic Voice of Amos as a Paradigm for Christians in the Public Square." Tyndale Bulletin 58/2 (2007): 161-182.

Lafferty, Theresa V. "The Prophetic Critique of the Priority of the Cult: A Study of Amos 5:21-24 and Isaiah 1:10-17." Unpublished PhD Thesis. The Catholic University of America, Washington, DC, 2012, 61. Cited 16 January 2021. Online:

http://aladinrc.wrlc.org/bitstream/handle/1961/9205/Lafferty_cua_0043A_100 87display.pdf?sequence $=1$.

Leliovskyi, Mykola. "Exegetical Study of Amos 5:18-27." 26 pages. Cited 12 February 2021.

Online:

https://www.academia.edu/14064690/Exegetical_Study_of_Amos_5_18-27.

Masenya (Ngwan'a Mphahlele), Madipoane. "Professor David Tuesday Adamo's Biblical Scholarship on Women: Reflections from an Africa-South African Mosadi." Old Testament Essays 33/2 (2020): 348-362. DOI: https://doi.org/10.17159/2312-3621/2020/v33n2a11.

Malchow, Bruce V. Social Justice in the Hebrew Bible. Collegeville, MN: The Liturgical Press, 1996.

Masenya (Ngwan'a Mphahlele), Madipoane and Hulisani Ramantswana. "Anything New under the Sun of African Biblical Hermeneutics in South African Old Testament Scholarship? Incarnation, Death and Resurrection of the Word in Africa."Verbum et Ecclesia 36/1 2015): https://dx.doi.org/10.4102/ve.v36i1.1353.

Mbachirin, Abraham. "The Will to Arise: Theological and Political Themes in African Christianity and the Renewal of Faith and Identity." Journal of Church and State 49/3 (2007): 566-567. https://doi.org/10.1093/jcs/49.3.566.

Meyer, R. "The Involvement of the Church in the Blueprints of Society." The Dutch Reformed Church in Africa. Supplement to the Ligstraal (October 1991):10-18.

Milgrom, Jacob. Pomegranates and Golden Bells: Studies in Biblical, Jewish, and near Eastern Ritual, Law, and Literature in Honor of Jacob Milgrom. Winona Lake: Eisenbrauns, 1995. 
Naude, C.F.B. "A Vision for the Future." Pages 250-355 in Christianity and Democracy in South Africa: Christian Responsibility for Political Reflection and Service. Edited by Bernie J. Van der Walt and Rita Swanepoel. Potchefstroom: The Institute for Reformational Studies, 1996.

Niehaus, Joseph. "Amos." Pages 315-494 in The Minor Prophets: An Exegetical and Expository Commentary. Vol. 1: Hosea, Joel and Amos. Edited by Thomas E. McComiskey. Grand Rapids: Baker Book House, 1992.

Osuagwu, Tochukwu. "An Ideological-critical Interpretation of Justice and Righteousness in Amos 5." Unpublished MA Thesis, University of Pretoria, Pretoria, South Africa. 2016.https://repository.up.ac.za/bitstream/handle/2263/63000/Osuagwu_Ideol ogical_2016.pdf?sequence=1\&isAllowed=y.

Otuibo, Chris A. Amos: A Challenge to Nigerian Church and Society. Ibadan: St. Paul's Society, 2006.

Oyejimi, Joseph A. Prophetical Ministry in the Church. Ilesa: Living Truth Publisher, 2017.

Paul, Shalom M. Amos. Hermeneia. Philadelphia: Fortress Press, 1991.

Pedersen, J 1957. "The Role Played by Inspired Persons among the Israelite and Arabs." Pages 127-142 in Studies in Old Testament Prophecy. Edited by H.H. Rowley. Edinburgh: T \& T Clark.

Pillay, Jerry. "The Church as a Transformation and Change Agent." HTS Teologiese Studies/Theological Studies 73/3 (2017): 12. https://dx.doi.org/10.4102/hts.v73i3.4352.

Snyman, Stephanus D. “Amos, Prophet of God's Justice.” Pages 17-26 in The Lion Has Roared: Theological Themes in the Prophetic Literature of the Old Testament. Edited by H.G.L. Peels and S.D. Snyman. Eugene: Wipf \& Stock, 2012.

Strong, James. New Strong's Dictionary of Hebrew and Greek Words. Nashville: Thomas Nelson, 1986.

Strydom, Johannes G. and Wilhelm J. Wessels. Prophetic Perspective on Power and Social Justice. Pretoria: Biblia Publishers, 2000.

Sweeney, Marvin A. “Amos." Pages 235-254 in The Twelve Prophets. Vol. 1: Hosea, Joel, Amos, Obadiah, Jonah. Berit Olam. Edited by D.W. Cotter. Collegeville: Liturgical Press, 2000.

Udoekpo, Michael U. Rethinking the Prophetic Critique of Worship in Amos 5 for Contemporary Nigeria and the USA. Eugene: Pickwick.

Umeanolue, Ikenna L. "Critique against Social Injustice in the Book of Amos: Its Relevance to Development in Nigeria." UJAH 19/2 (2018): 182- 198.

Wax, Kevin P. "The Intricate Relationship between Politics and Religion in the Hebrew Bible: The Prophet Amos as a Case Study." Unpublished PhD Thesis. Stellenbosch University, Stellenbosch, South Africa. Cited 10th January 2021. Online: file:///C:/Users/user/Downloads/wax_intricate_2013.pdf.

Wolff, Hans W. Joel and Amos: A Commentary on the Books of the Prophets Joel and Amos. Hermeneia. Philadelphia: Fortress, 1984.

Woodbridge, Noel and Semmelink, Willem. "The Prophetic Witness of Amos and Its Relevance for Today's Church in African Countries for Promoting Social Justice, Especially in Democratic South Africa." Conspectus: The Journal of 
Akintola, “Amos' Call for Social Justice,” OTE 34/2 (2021): 404-427

the South Africa Theology. Cited 10 January 2021. Online: https://www.sats.edu.za/userfiles/Noel\%20Woodbridge.pdf.

Dr. Godwin Olutayo Akintola, University of South Africa. Email: akintolag03@gmail.com. ORCID: https://orcid.org/0000-0002-1260-9724. 